\title{
Determination of Suitable Variety and Plants per Stand of Cowpea (Vigna Unguiculata L.Walp) in the Sandy Soil, Sudan
}

\author{
Ahmed M. El Naim*, Abdelrhim A. Jabereldar, Salaheldeen E. Ahmed, Feisal M. Ismaeil, \\ Elshiekh A. Ibrahim
}

Department of Crop Sciences, Faculty of Natural Resources and Environmental Studies, University of Kordofan, Elobied, Sudan

\begin{abstract}
The study was conducted to determine the effects of four different numbers of plants per stand on the performance of three cowpea varieties under rain-fed conditions. A field experiment was conducted for two successive rainy seasons (2007/08-2008/09) in sandy soil of North Kordofan State, Sudan. The three varieties of cowpea (BLedi, an old local cultivar and two recently improved cultivars, Haydoob and Eien Elgazal) were sown in four patterns (one, two, three and four plants per stand). The experiment was laid out in a randomized complete block design (RCBD) in four replications. The results showed that, plants/stand had a significant effect on most of the attributes measured. Increased plants/stand significantly increased grain yield per unit area and reduced the number of pods per plant, 100-grain weight, grain yield per plant and harvest index. The local cultivar was late in maturity and had heavier 100 -grain weight, greater grain yield per plant, greater final grain yield ( $\mathrm{t} / \mathrm{ha}$ ). The Ein Elgazal was earlier in maturity and scored the highest values of harvest index.
\end{abstract}

Keywords Grain Yield, Cowpea, Rain-Fed, Harvest Index

\section{Introduction}

Cowpea (Vigna unguiculata L.Walp.) is an ancient leguminous crop, which has been grown throughout the tropics and sub tropics. The seeds are a major source of plant proteins and vitamins for man, feed for animals, and also a source of cash income. The young leaves and immature pods are eaten as vegetables. Conservative estimates suggest that greater than 12.5 million hectares are planted annually with cowpea around the world. The total world production is estimated about 3.3 million tons of dry grain (El Naim and Jabereldar, 2010).

In Sudan, cowpea is mainly grown under rain-fed conditions in Kordofan and Darfour state, which the rainfall ranged between $350-500 \mathrm{~mm}$, only very small scattered batches had been grown under irrigation in the northern Sudan. Cowpea also plays an important role in providing soil nitrogen to cereal crops (such as maize, millet, and sorghum) when grown in rotation, especially in areas where poor soil fertility is a problem. It does not require a high rate of nitrogen fertilization; its roots have nodules in which soil bacteria called Rhizobia help to fix nitrogen from the air. Cowpea can be used as a feed (grazed, or harvested for

* Corresponding author:

naim17amn@yahoo.com (Ahmed M. El Naim)

Published online at http://journal.sapub.org/als

Copyright (C) 2012 Scientific \& Academic Publishing. All Rights Reserved fodder), or its pods can be harvested before maturity stage vide complementary proteins to cereals. Some people eat both fresh pods and leaves and the dried seeds are popular ingredients in various dishes. Cowpea seed contains (20 $24 \%$ ) protein, $63.3 \%$ carbohydrates and $1.9 \%$ fat (Davis, 1991)

The uses of Cowpea in Sudan are diversified. The seeds can be boiled in Sudan with water and eaten as "Ballila". They can also be cooked with meat, tomatoes and onions into a thick soup, eaten with pancake and /or bread. The paste form soaked seeds can be fried with oil as small doughnuts (Ta ammia) which can be eaten alone or with bread.

Cowpea grain and fodder yields are very low in West Africa and Sudan, the main problems limiting production and expansion of cowpea as pointed out by El Naim and Jabereldar (2010) and El Naim et al. (2011) are: Low yield potential of existing cultivars, low density of cowpea and Limited use of certified seeds by the cowpea growers, due to deficient marketing and failure to convince the farmers about the advantages of planting certified seeds versus their own seeds. The research focused on detecting the suitable variety, plants per stand and evaluating the performance of the variety in the rain-fed

\section{Materials and Methods}

A field experiment was conducted for two successive rainy seasons $(2007 / 08-2008 / 09)$ in Kazgail area $(50 \mathrm{~km}$ 
south Elobeid), in North Kordofan state (latitude $111^{\prime}$ - 16 $30^{\prime} \mathrm{N}$; longitude $27-32 \mathrm{E}$ ). The climate of the area is arid and semi arid zone. The mean annual rainfall ranges between $350-500 \mathrm{~mm}$. The soil is sandy with low fertility. Average maximum daily temperature varied between 30 and $35 \mathrm{C}$ throughout the year (Gebauer, 2005; El Naim and Ahmed, 2010).

The experiment was laid out in a randomized complete block design with three replications. The experimental plot was $4 \times 4$ meters. Treatments consisted of four levels of plants per stands one, two, three and four plants, designated as $P_{1}$, $\mathrm{P}_{2}, \mathrm{P}_{3}$ and $\mathrm{P}_{4}$ respectively. Three varieties of cowpea: local, Hydoob and Ein Elgaza were used and designated as $V_{1}, V_{2}$ and $\mathrm{V}_{3}$ respectively. Sowing was on $25^{\text {th }}$ of July, 2007 and 2008. Seeds were sown in holes at spacing of $60 \times 30 \mathrm{~cm}$, five seeds were placed in each hole, which were thinned, two weeks later, to $1,2,3$ and 4 plants. Manual weeding was practiced twice during both seasons.

A sample of four plants was taken randomly from two central rows in each experimental unit at to measure the following growth attributes:

Plant height,

Stem diameter

Number of branches per plant

Leaf area index, Leaf area index (L.A.I) is a dimensionless quantity. It is the leaf area (upper side only) per unit area of land below. It is expressed as $\mathrm{m}^{2}$ leaf area per $\mathrm{m}^{2}$ ground area. Leaf area was determined using the punch method (Watson and Watson, 1953) by taking 50 discs and was calculated using the following relationship:-

Leaf area $=\underline{\text { leaf area of discs } \mathrm{x} \text { dry weight of leaves }}$ Dry weight of leaf discs

The leaf area index (L.A.I), was determined as follows:-

Leaf area index $=\underline{\text { leaf area of plant }}$

Plant ground area

Yield attributes: A sample of five plants was taken randomly from two central rows in each experimental unit at physiological maturity to measure the following yields attributes:

Number of pods per plant

Number of grains per pods

100 -grain weight and

Grain yield ( $\mathrm{t} / \mathrm{ha}$ ).

Harvest index was determined by using the following formula:-

$$
\text { Harvest index }=\frac{\text { Economical Yield }}{\text { Biological yield }} 100
$$

Data were analyzed statistically using analysis of variance according to Gomez and Gomez (1984) procedure for a randomized complete block design. The differences of means were identified by Duncan's Multiple Range Test (DMRT) at $\mathrm{P} \geq 0.05$.

\section{Results and Discussion}

Generally, increasing the plant population increased competition among plants for soil moisture, nutrient, light and carbon dioxide. Moreover, the low population plants grew as isolated units for most of their early life and interfered less with each other than at higher densities. This might explain the significant effect of plant population on most of the parameters measured in the present study. Difference in growth attributes observed among cultivars may be to the growth habit and to the genetically potential of each genotype.

Increasing plant per stand decreased plant height (Table 1). Similar results were obtained by (El Naim and Jabereldar, 2010) who found plants produced at highest densities were taller and more sparsely branches. On the contrary, Mohamed (2002) reported that plant density had no significant effect on plant height. The local variety (Beldi) had significantly taller plants compared to other varieties. Differences among varieties in plant height were reported by El Naim et al (2010) and El Naim et al. (2010). Stem diameter was affected by plant population in this study (Table 2). The low plant population had a wide stem diameter compared with the high population, this may be attributed to the better soil moisture availability, decreased plant competition and increased light penetration through plant canopy at low plant population. The variation in stem diameter among cultivars might be referred to genotypic characters. Increasing plant per stand decreased number of branches per plant (Table 2). These results are in agreement with the previous findings reported by many workers (Miller, 1988; El Naim and Jabereldar, 2010; El Naim et al., 2010) .They showed that increased plant densities reduced the number of branches per plant. The local variety (Beldi) had the greatest number of branches per plant than other varieties. The leaf area index decreased with the increasing plant density (Table 2). Similar results were obtained by El Naim and Jabereldar (2010) who found that leaf area index tends to decrease with increasing plant densities. The local varieties (Beldi) had the greater leaf area index than others.

Table 1. Effect of Varieties and Plants per Stand on Plant Height and Stem Diameter of Cowpea.

\begin{tabular}{|c|c|c|c|c|}
\hline \multirow{2}{*}{ Treatments } & \multicolumn{2}{|c|}{$2006 / 07$} & \multicolumn{2}{c|}{$2007 / 08$} \\
\cline { 2 - 5 } & $\begin{array}{c}\text { Plant } \\
\text { height }\end{array}$ & $\begin{array}{c}\text { Stem } \\
\text { diameter }\end{array}$ & Plant height & $\begin{array}{c}\text { Stem } \\
\text { diameter }\end{array}$ \\
\hline $\mathrm{P}_{1}$ & $48.3^{\mathrm{c}}$ & $0.47^{\mathrm{a}}$ & $51.0^{\mathrm{c}}$ & $0.49^{\mathrm{a}}$ \\
\hline $\mathrm{P}_{2}$ & $52.6^{\mathrm{a}}$ & $0.34^{\mathrm{a}}$ & $53.0^{\mathrm{b}}$ & $0.33^{\mathrm{bc}}$ \\
\hline $\mathrm{P}_{3}$ & $53.5^{\mathrm{a}}$ & $0.34^{\mathrm{a}}$ & $54.8^{\mathrm{b}}$ & $0.31^{\mathrm{cd}}$ \\
\hline $\mathrm{P}_{4}$ & $55.2^{\mathrm{a}}$ & $0.24^{\mathrm{b}}$ & $56.5^{\mathrm{a}}$ & $0.27^{\mathrm{d}}$ \\
\hline $\mathrm{SE}_{ \pm}$ & 0.5 & 0.01 & 0.6 & 0.01 \\
\hline $\mathrm{V}_{1}$ & $75.7^{\mathrm{a}}$ & $0.31^{\mathrm{a}}$ & $75.0^{\mathrm{a}}$ & $0.40^{\mathrm{a}}$ \\
\hline $\mathrm{V}_{2}$ & $39.8^{\mathrm{b}}$ & $0.42^{\mathrm{b}}$ & $39.3^{\mathrm{b}}$ & $0.36^{\mathrm{a}}$ \\
\hline $\mathrm{V}_{3}$ & $44.1^{\mathrm{c}}$ & $0.31^{\mathrm{c}}$ & $44.5^{\mathrm{c}}$ & $0.29^{\mathrm{b}}$ \\
\hline $\mathrm{SE} \pm$ & 0.45 & 0.01 & $0.52^{\mathrm{b}}$ & 0.01 \\
\hline $\mathrm{CV} \%$ & 9.4 & 6.8 & 5.1 & 3.4 \\
\hline
\end{tabular}

Similar letters are not significantly different at the 0.05 level of probability according to Duncan Multiple Range Test 
Table 2. Effect of Varieties and Plants per Stand on Number of branches per Plant and lea Area Index (L.A.I) of Cowpea.

\begin{tabular}{|c|c|c|c|c|}
\hline \multirow{2}{*}{ Treatments } & \multicolumn{2}{|c|}{$2006 / 07$} & \multicolumn{2}{c|}{$2007 / 08$} \\
\cline { 2 - 5 } & $\begin{array}{c}\text { No. of } \\
\text { Branches } \\
\text { per Plant }\end{array}$ & L. A. I & $\begin{array}{c}\text { No. of } \\
\text { Branches per } \\
\text { Plant }\end{array}$ & L. A. I \\
\hline $\mathrm{P}_{1}$ & $8.67^{\mathrm{a}}$ & 0.80 & $7.67^{\mathrm{a}}$ & 0,89 \\
\hline $\mathrm{P}_{2}$ & $6,22^{\mathrm{b}}$ & 0.87 & $5.45^{\mathrm{b}}$ & 0.81 \\
\hline $\mathrm{P}_{3}$ & $6.22^{\mathrm{b}}$ & 0.88 & $5.33^{\mathrm{b}}$ & 0.89 \\
\hline $\mathrm{P}_{4}$ & $6.11^{\mathrm{b}}$ & 1.01 & $5.44^{\mathrm{b}}$ & 1.02 \\
\hline $\mathrm{SE}_{ \pm}$ & 0.33 & 0.02 & 0.17 & 0.02 \\
\hline $\mathrm{V}_{1}$ & $5.50^{\mathrm{b}}$ & 1.03 & $5.67^{\mathrm{b}}$ & 1.16 \\
\hline $\mathrm{V}_{2}$ & $7.67^{\mathrm{a}}$ & 0.82 & $6.00^{\mathrm{a}}$ & 0.80 \\
\hline $\mathrm{V}_{3}$ & $7.27^{\mathrm{a}}$ & 0.84 & $6.25^{\mathrm{a}}$ & 0.75 \\
\hline $\mathrm{SE}+$ & 0.29 & 0.02 & 0.14 & 0.02 \\
\hline $\mathrm{CV} \%$ & 23.5 & 7.9 & 14.2 & 6.8 \\
\hline
\end{tabular}

Similar letters are not significantly different at the 0.05 level of probability according to Duncan Multiple Range Test

Plants/stand had no significant effect on time to $50 \%$ flowering and $95 \%$ maturity (Table 3). Days taken to flowering or maturity were similar when the crop was sown on low or high population.

Table 3. Effect of Varieties and Plants per Stand on 50\% Flowering and 95\% Physiological Maturity of Cowpea.

\begin{tabular}{|c|c|c|c|c|}
\hline \multirow{2}{*}{ Treatments } & \multicolumn{2}{|c|}{$2006 / 07$} & \multicolumn{2}{c|}{$2007 / 08$} \\
\cline { 2 - 5 } & $\begin{array}{c}50 \% \\
\text { Flowering }\end{array}$ & $\begin{array}{c}95 \% \\
\text { Maturity }\end{array}$ & $\begin{array}{c}50 \% \text { Flow- } \\
\text { ering }\end{array}$ & $\begin{array}{c}95 \% \\
\text { Maturity }\end{array}$ \\
\hline $\mathrm{P}_{1}$ & $48.3^{\mathrm{b}}$ & 70.5 & $48.3^{\mathrm{b}}$ & 71.4 \\
\hline $\mathrm{P}_{2}$ & $48.5^{\mathrm{b}}$ & 71.3 & $48.5^{\mathrm{b}}$ & 72.1 \\
\hline $\mathrm{P}_{3}$ & $49.8^{\mathrm{a}}$ & 72.9 & $49.8^{\mathrm{a}}$ & 71.7 \\
\hline $\mathrm{P}_{4}$ & $51.0^{\mathrm{a}}$ & 71.6 & $49.7^{\mathrm{a}}$ & 70.8 \\
\hline $\mathrm{SE}_{ \pm}$ & 0.21 & 0.43 & 0.32 & 0.43 \\
\hline $\mathrm{V}_{1}$ & $61.8^{\mathrm{a}}$ & $101.4^{\mathrm{a}}$ & $61.7^{\mathrm{a}}$ & $101.5^{\mathrm{a}}$ \\
\hline $\mathrm{V}_{2}$ & $44.2^{\mathrm{b}}$ & $61.5^{\mathrm{b}}$ & $44.5^{\mathrm{b}}$ & $61.6^{\mathrm{b}}$ \\
\hline $\mathrm{V}_{3}$ & $42.1^{\mathrm{c}}$ & $51.7^{\mathrm{c}}$ & $40.9^{\mathrm{b}}$ & $51.3^{\mathrm{c}}$ \\
\hline $\mathrm{SE} \pm$ & 0.18 & 0.21 & 0.28 & 0.43 \\
\hline $\mathrm{CV} \%$ & 23.3 & 7.3 & 19.0 & 4.1 \\
\hline
\end{tabular}

Similar letters are not significantly different at the 0.05 level of probability according to Duncan Multiple Range Test

This is in line with Elawad (2000), Hamad (2004) and Johnson (1994). They stated that, plant population had no effect on the time to flowering and maturity. Cultivars had a significant effect on phenological attributes. This may be attributed to the genetic characteristic of variety. Duke (1981), Elawad (2000) and Hamad (2004) reported that, the introduced cultivars were significantly earlier flowering and maturing compared with the local cultivars. The results obtained in the present study showed that, the introduced cultivars (Hydoob and Ein Elgaza) reached 50\% flowering and 95\% physiological maturity earlier than the local cultivar.

Plants per stand had a significant effect on most yield components measured in this study. Generally increasing plants stand decreased the number of pods per plant in both seasons (Table 4). This reduction may be attributed to the interference among branches. These findings are in accord with the previous results reported by Weber et al (1966) and Hamad (2004). They indicated that plants produced at the highest densities set fewer pods than those at the lowest densities. The plants per stand had no significant effect on number of grains per pod in both seasons (Table 4). This is in agreement with the finding of Salih (1992) and Mohammed (2002). They found that plant population had a little or no effect on the number of seeds per pod. However the cultivar (Hydoob) had the greatest seed number per pod. The variation in number of seeds per pod among cultivars might be referred to genotype.

Table 4. Effect of Varieties and Plants per Stand on Number of Pods per Plant and Number of Grains per Pod of Cowpea.

\begin{tabular}{|c|c|c|c|c|}
\hline \multirow{2}{*}{ Treatments } & \multicolumn{2}{|c|}{$2006 / 07$} & \multicolumn{2}{c|}{$2007 / 08$} \\
\cline { 2 - 5 } & $\begin{array}{c}\text { No. of } \\
\text { pods/plant }\end{array}$ & $\begin{array}{c}\text { No. of } \\
\text { grains/pod }\end{array}$ & $\begin{array}{c}\text { No. of } \\
\text { pods/plant }\end{array}$ & $\begin{array}{c}\text { No. of } \\
\text { grains/ } \\
\text { pod }\end{array}$ \\
\hline $\mathrm{P}_{1}$ & $15.3^{\mathrm{a}}$ & 9.8 & $15.3^{\mathrm{a}}$ & 9.5 \\
\hline $\mathrm{P}_{2}$ & $8.1^{\mathrm{b}}$ & 8.6 & $9.2^{\mathrm{b}}$ & 8.6 \\
\hline $\mathrm{P}_{3}$ & $7.1^{\mathrm{c}}$ & 8.5 & $7.6^{\mathrm{c}}$ & 8.5 \\
\hline $\mathrm{P}_{4}$ & $6.2^{\mathrm{d}}$ & 8.6 & $7.0^{\mathrm{c}}$ & 8.5 \\
\hline $\mathrm{SE}_{ \pm}$ & 0.29 & 0.30 & 0.39 & 0.33 \\
\hline $\mathrm{V}_{1}$ & $9.0^{\mathrm{a}}$ & $7.8^{\mathrm{c}}$ & $8.8^{\mathrm{b}}$ & $7.7^{\mathrm{c}}$ \\
\hline $\mathrm{V}_{2}$ & $8.7^{\mathrm{b}}$ & $10.5^{\mathrm{a}}$ & $10.5^{\mathrm{a}}$ & $10.3^{\mathrm{a}}$ \\
\hline $\mathrm{V}_{3}$ & $8.6^{\mathrm{b}}$ & $8.5^{\mathrm{b}}$ & $10.0^{\mathrm{a}}$ & $8.3^{\mathrm{b}}$ \\
\hline $\mathrm{SE} \pm$ & 0.18 & 0.21 & 0.28 & 0.43 \\
\hline $\mathrm{CV} \%$ & 23.3 & 7.3 & 19.0 & 15.0 \\
\hline
\end{tabular}

Similar letters are not significantly different at the 0.05 level of probability according to Duncan Multiple Range Test

Plants/stand had a significant effect on mean 100-grain weight in both seasons (Table 5). Decreased plant population resulted in increased 100-grain weight.

Table 5. Effect of Varieties and Plants per Stand on 100-Grain and Grain Yield (g/plant) of Cowpea.

\begin{tabular}{|c|c|c|c|c|}
\hline \multirow{2}{*}{ Treatments } & \multicolumn{2}{|c|}{$2006 / 07$} & \multicolumn{2}{c|}{$2007 / 08$} \\
\cline { 2 - 5 } & $\begin{array}{c}100 \text {-grain } \\
\text { weight }\end{array}$ & $\begin{array}{c}\text { Grain } \\
\text { yield } \\
\text { (g/plant) }\end{array}$ & $\begin{array}{c}100 \text {-Grain } \\
\text { weight }\end{array}$ & $\begin{array}{c}\text { Grain } \\
\text { yield } \\
\text { (g/plant })\end{array}$ \\
\hline $\mathrm{P}_{1}$ & $18.6^{\mathrm{a}}$ & $13.5^{\mathrm{a}}$ & $18.6^{\mathrm{a}}$ & $13.8^{\mathrm{a}}$ \\
\hline $\mathrm{P}_{2}$ & $17.1^{\mathrm{b}}$ & $12.8^{\mathrm{b}}$ & $18.4^{\mathrm{b}}$ & $12.7^{\mathrm{b}}$ \\
\hline $\mathrm{P}_{3}$ & $17.4^{\mathrm{b}}$ & $12.2^{\mathrm{b}}$ & $18.5^{\mathrm{b}}$ & $12.2^{\mathrm{b}}$ \\
\hline $\mathrm{P}_{4}$ & $16.7^{\mathrm{b}}$ & $11.8^{\mathrm{b}}$ & $19.1^{\mathrm{a}}$ & $11.7^{\mathrm{b}}$ \\
\hline $\mathrm{SE}_{ \pm}$ & 0.21 & 0.43 & 0.32 & 0.43 \\
\hline $\mathrm{V}_{1}$ & $22.79^{\mathrm{a}}$ & $19.52^{\mathrm{a}}$ & $24.8^{\mathrm{a}}$ & $18.2^{\mathrm{a}}$ \\
\hline $\mathrm{V}_{2}$ & $14.1^{\mathrm{c}}$ & $6.7^{\mathrm{c}}$ & $13.9^{\mathrm{c}}$ & $6.2^{\mathrm{c}}$ \\
\hline $\mathrm{V}_{3}$ & $16.6^{\mathrm{b}}$ & $11.5^{\mathrm{b}}$ & $17.4^{\mathrm{b}}$ & $12.1^{\mathrm{b}}$ \\
\hline $\mathrm{SE}_{-}$ & 0.18 & 0.21 & 0.28 & 0.43 \\
\hline $\mathrm{CV}$ & 27.5 & 21.0 & 19.0 & $24.5^{2}$ \\
\hline
\end{tabular}

Similar letters are not significantly different at the 0.05 level of probability according to Duncan Multiple Range Test

This may be due to better availability of nutrients and 
better translocation of photosynthates from source to sink and may be due higher accumulation of photosynthates in the seeds. Contrasting results were reported by Taha (1988) and Mohamed (2002). They found that 100-grain weight was not affected by plant population. The local cultivar (Beldi) had heavier seed weight than the introduced cultivars. This may be due to better translocation and partitioning of assimilates from source to sink (grains).

Generally, increasing plants / stand decreased grain yield per plant. This was primarily because of reduced number of pods per plant and number of grains per pod at the higher plant population. Similar results were obtained by many workers (Hamad (2004), Ball et al (2001),Salih and Bahrani (2000)). The local cultivar (Beldi) had significantly higher seed yield per plant than the improved one. This is because of heavier grain weight of the local cultivar.

The final grain yield per unit area was greatly affected by plant population (Table 6). Thus, increasing plant per stand increased grain yield per unit area.

Table 6. Effect of Varieties and Plants per Stand on Final Grain Yield (t/ha) and Harvest Index of Cowpea.

\begin{tabular}{|c|c|c|c|c|}
\hline \multirow{2}{*}{ Treatments } & \multicolumn{2}{|c|}{$2006 / 07$} & \multicolumn{2}{c|}{$2007 / 08$} \\
\cline { 2 - 5 } & $\begin{array}{c}\text { Grain } \\
\text { yield } \\
(\mathrm{t} / \mathrm{ha})\end{array}$ & $\begin{array}{c}\text { Harvest } \\
\text { index }\end{array}$ & $\begin{array}{c}\text { Grain } \\
\text { yield } \\
\text { (t/ha) }\end{array}$ & $\begin{array}{c}\text { Harvest } \\
\text { index }\end{array}$ \\
\hline $\mathrm{P}_{1}$ & $0.81^{\mathrm{c}}$ & $20.0^{\mathrm{c}}$ & $0.75^{\mathrm{c}}$ & $18.4^{\mathrm{b}}$ \\
\hline $\mathrm{P}_{2}$ & $1.46^{\mathrm{b}}$ & $15.1^{\mathrm{d}}$ & $1.24^{\mathrm{b}}$ & $14.5^{\mathrm{c}}$ \\
\hline $\mathrm{P}_{3}$ & $1.93^{\mathrm{b}}$ & $23.1^{\mathrm{a}}$ & $1.77^{\mathrm{b}}$ & $20.7^{\mathrm{a}}$ \\
\hline $\mathrm{P}_{4}$ & $2.57^{\mathrm{a}}$ & $19.4^{\mathrm{b}}$ & $2.41^{\mathrm{a}}$ & $19.4^{\mathrm{b}}$ \\
\hline $\mathrm{SE} \pm$ & 0.21 & 0.43 & 0.32 & 0.43 \\
\hline $\mathrm{V}_{1}$ & $3.85^{\mathrm{a}}$ & $7.0^{\mathrm{c}}$ & $3.52^{\mathrm{a}}$ & $6.7^{\mathrm{c}}$ \\
\hline $\mathrm{V}_{2}$ & $1.15^{\mathrm{c}}$ & $23.4^{\mathrm{b}}$ & $1.28^{\mathrm{c}}$ & $21.2^{\mathrm{b}}$ \\
\hline $\mathrm{V}_{3}$ & $2.71^{\mathrm{b}}$ & $28.3^{\mathrm{a}}$ & $2.44^{\mathrm{b}}$ & $27.7^{\mathrm{a}}$ \\
\hline $\mathrm{SE} \pm$ & 0.18 & 0.21 & 0.28 & 0.43 \\
\hline $\mathrm{CV} \%$ & 23.3 & 20.0 & 19.0 & 30.0 \\
\hline
\end{tabular}

Similar letters are not significantly different at the 0.05 level of probability according to Duncan Multiple Range Test

This may be attributed to the highest number of plants per unit area. Similar result was obtained by Herbert and Baggerman (1982) who found that the highest grain yield was obtained with the higher plant density. The local variety (Beldi) gave the highest seed yield per unit area compared to the other two varieties during the two seasons. The grain yield in the first season is relatively higher than the second season. This is because, it receive a highest amount of rainfall. Plant per stand had significant effect on harvest index (Table 6). Higher plant population decreased harvest index due to greater dry matter of the shoot. Similar results were obtained by Weber et al, (1966) who reported that lower plant population tended to increase harvest index. The introduced cultivars had a greater harvest index compared with the local cultivar. The may be due to higher seed yield of introduced cultivars. Similar results were reported by Suli- man (2000). who found that the introduced cultivars had greater harvest index than the local cultivar.

\section{Conclusions}

Increased plants/stand increased grain yield ( $\mathrm{t} / \mathrm{ha})$. The local cultivar (Beldi) gave the highest grain yield per unit area, but it seems to be a fodder type than grain type because it is late maturing with lowest harvest index. From the results obtained, it can be concluded that, if the crop is grown for grain yield, three plants per stand were recommended in North Kordofan State, Sudan to earn maximum yield.

\section{REFERNCES}

[1] Ball, R. A., R.W., McNew, E.D., Vories, T.C., Keisling and L.C., Purcell, 2001. Path analyses of population density effects on short-season soybean yield. Abstract Agronomy Journal, Vol.93 (1):187-195

[2] Davis, D.W., E. A., Oelke, E. S., Oplinger, J. D., Doll, C.V., Hanson and D., Putnam, 1991. Field crops manure, University of Mipesota, St Paul, MN5510. University of Wisconsin-Madison, W1 53706

[3] Elawad, H.O., 2000. The performance of selected cowpea (Vigna unguiculata L.Walp).Varieties in the sandy rainfed areas of Kordofan. Agricultural Research Corporation, Elobied, Sudan

[4] El Naim, A. M., Jabereldar, A. A. And Mohammed, E. A. 2011. Effect of Seed Rate and Cultivar on Yield and Yield Compononents of Cowpea (Vigna unguiculata L, Walp) in Kordofan of Sudan. International Journal of Current Research, 2(1): 142-147

[5] El Naim A, M. and Jabereldar, A. A. 2010. Effect of Plant density and cultivar on growth and yield of cowpea (Vigna unguiculata L.Walp). Australian Journal of Basic and Applied Sciences, 4(8): 3148-3153

[6] El Naim, A. M. and Ahmed, S. E. 2010. Effect of weeding frequencies on growth and yield of two roselle (Hibiscus sabdariffaL) Varieties under rain fed. Australian Journal of Basic and Applied Sciences, 4(9):4250- 4255

[7] El Naim, A. M., El day, E. M. and Ahmed, A. A. $2010^{\mathrm{a}}$. Effect of plant density on the performance of some sesame (Sesamum indicum L) cultivars under Rain -fed. Research Journal of Agriculture and Biological Sciences, 6(4): 498-504

[8] El Naim, A. M., Hagelsheep, A. M., Abdelmuhsin, M. E. and Abdalla, A. E. $2010^{\mathrm{b}}$. Effect of Intra-row spacing on growth and yield of three cowpea (Vigna unguiculata L.Walp) varieties under rainfed. Research Journal of Agriculture and Biological Sciences, 6(5): 623-629

[9] El Naim, A. M., Eldoma, M. A. and Abdalla, A. E. $2010^{\mathrm{a}}$. Effect of weeding frequencies and plant density on vegetative growth characteristic of groundnut (Arachis hypogaea L.) in North Kordofan of Sudan. International Journal of Applied Biology and Pharmaceutical Technology 1(3):1188-1193 
[10] Gebauer, J. 2005. Plant species diversity of home gardens in Elobeid, central Sudan. Journal of Agriculture and Rural Development in the tropics and subtropics, Vol. (2). 106

[11] Gomez, K. A. and Gomez, A. A., 1984. Randomized complete block design analysis. In: Statistical procedures for agricultural research. John Willey and Sons, New York

[12] Hamad, M.S., 2004. Effect of planting density on the performance of three cultivars of cowpea, M.Sc thesis, University of Khartoum, Sudan

[13] Herbert, S. J., and Baggerman, F. D., 1982. Cowpea response to row, density, and irrigation. Abstract Agron-sci Journal. Vol. (6).75.

[14] Miller, R. 1988. Legume cover crops for Northern California, small farm news. Small farm center, UC coop. Ext., UC

[15] Mohamed, L.Z., 2002. The effect of intra-row spacing and starter nitrogen fertilizer on growth and yield of cowpea (Vigna unguiculata L.Walp) .M.Sc thesis, University of Khartoum, Sudan

[16] Mohammed, A.S.E 1984. Growth and yield of cowpea as influenced by sowing date intra-row spacing inoculation and nitrogen fertilization. M.Sc. Thesis. University of Khartoum, Sudan
[17] Salih, F.A. 1992. Effect of watering interval and hill planting on faba bean seed yield and its components. FABIS News Letter, 31:17-20

[18] Salih, F. and Bahrani, M.J., 2000. Sunflower summer-plantin $\mathrm{g}$ yield as affected by plant population and nitrogen application rates, Iran Agricultural Research, 19 (1):63-72 IITA and JIRCAS

[19] Suliman, A.H., 2000. Effect of water stress at different stages of growth on the performance of cowpea cultivars (Vigna unguiculata.Walp.). M.Sc Thesis. University of Khartoum. Sudan

[20] Taha, M.B., 1988. Effect of population density on the yield of dry beans. Annual Report, 1988/89. 47-50 Hudeiba Research Station El Damer, Sudan

[21] Watson, D.L. and Watson, M. L. 1953. Comparative physiological studies on the growth of field crops. III. The effect on infection with beet yellows and beet mosaic viruses on the growth and yield of the sugar-beet root crop. Ann. Appl. Biol., 40: (1) 1- 37

[22] Weber, C.R., R.M., Shibles and D.E. Byth, 1966. Effect of plant population and row spacing on Soybean development and production. American Society of Agronomy Journal, Vol. (58):99-102, Madison, U.S.A 